Лапина М.А., Карпухин Д.В.

\title{
СТРУКТУРИРОВАНИЕ АДМИНИСТРАТИВНЫХ ПРАВОНАРУШЕНИЙ В ОБЛАСТИ РЫНКА ЦЕННЫХ БУМАГ В РОССИЙСКОМ ЗАКОНОДАТЕЛЬСТВЕ
}

\begin{abstract}
Аннотация: Рубеж XX - XXI вв. ознаменовался активным развитием рынка иенных бумаг в Российской Федерации. Принятие большого количества нормативных актов в указанной срере правоотношений обусловило возникновение проблем, связанных со структурированием составов административных правонарушений; определения мер государственного принуждения за проступки в области рынка ценных бумаг; порядка рассмотрения дел об административных правонарушениях.Целью настоящей статьи является рассмотрения указанного комплекса проблем и формулировка предложений по совершенствованию административной юрисдикции в сфере рынка ценных бумаг. Методологическую основу статьи составили современные достижения теории познания. В процессе исследования применялись общефилософрский, теоретический, диалектика, системный метод, анализ, синтез, аналогия, дедукция, наблюдение, моделирование, традиционно правовые методы (формально-логический), а также методы, ис-пользуемые в конкретно-сочиологических исследованиях (статистические, экспертные оценки и др.). Анализ административных правонарушений в области рынка ценных бумаг, содержащихся в КоАП РФ, показывает, что в отличие от правонарушений в области финансов, налогов и сборов, административные правонарушения в указанной области, по сути, содержатся в одном кодифицированном нормативном правовом акте - КоАП РФ. Последний вариант представляется наиболее оптимальным и его необходимо взять за основу при реформировании административно-юрисдикционного законодательства в области финансов, налогов и сборов, страхования, рынка ценных бумаг.
\end{abstract}

Ключевые слова: ответственность, правонарушение, финансы, юрисдикция, Банк, принуждение, контроль, санкция, состав, признаки.

A дминистративные правонарушения в области рынка ценных бумаг, изложенные в главе 15 КоАП РФ можно условно классифицировать на несколько групп в зависимости от конкретного сегмента административного управленческого правоотношения, составляющего порядок осуществления действий с ценными бумагами ${ }^{1}$.

Первый сегмент охватывает составы административных правонарушений, объектом кото-

\footnotetext{
1 Кодекс Российской Федерации об административных правонарушениях от 30.12.2001 № 195-Ф3 (ред. от 05.05.2014) (с изм. и доп., вступ. в силу с 22.06.2014) // СЗ РФ, 07.01.2002, № 1 (ч. 1), ст. 1 .
}

рых выступает порядок осуществления действий с ценными бумагами.

Второй сегмент охватывает составы административных правонарушений, посягающих на установленный порядок раскрытия информации на финансовых рынках.

Третий сегмент включает составы административных правонарушений, посягающих на порядок ведения реестров владельцев ценных бумаг.

Четвёртый сегмент охватывает правонарушения, посягающие на порядок подготовки и проведения общих собраний акщионеров.

Пятый сегмент охватывает правонарушения, совершаемые участниками рынка ценных бумаг.

Статья подготовлена по результатам исследований, выполненных за счет бюджетных средств по Государственному заданию Финуниверситета 2014 года. 
Таблица 1.

\begin{tabular}{|c|c|c|}
\hline Норма & Наименование & Содержание \\
\hline $\begin{array}{l}\text { Статья } 15.17 \\
\text { КоАП РФ }\end{array}$ & $\begin{array}{l}\text { Недобросовестная эмис- } \\
\text { сия ценных бумаг }\end{array}$ & $\begin{array}{l}\text { Данная статья предусматривает административную ответственность за нарушение эмитен- } \\
\text { том установленного федеральными законами и принятыми в соответствии с ними иными } \\
\text { нормативными правовыми актами порядка (процедуры) эмиссии ценных бумаг, если это } \\
\text { действие не содержит уголовно наказуемого деяния. }\end{array}$ \\
\hline $\begin{array}{l}\text { Статья } 15.18 \\
\text { КоАП РФ }\end{array}$ & $\begin{array}{c}\text { Незаконные операции с } \\
\text { эмиссионными ценными } \\
\text { бумагами }\end{array}$ & $\begin{array}{l}\text { Состав административного правонарушения, предусмотренный указанной статьёй } 15.18 \\
\text { КоАП РФ, предусматривает административную санкцию за совершение профессиональ- } \\
\text { ным участником рынка ценных бумаг операций, связанных с переходом прав на эмис- } \\
\text { сионные ценные бумаги, до регистрации отчета об итогах их выпуска (дополнительного } \\
\text { выпуска) в случае, если регистрация такого отчета предусмотрена законодательством и } \\
\text { если эти действия не содержат уголовно наказуемого деяния. }\end{array}$ \\
\hline $\begin{array}{l}\text { Статья } \\
15.20 . \\
\text { КоАП РФ }\end{array}$ & $\begin{array}{c}\text { Воспрепятствование } \\
\text { осуществлению прав, } \\
\text { удостоверенных ценными } \\
\text { бумагами }\end{array}$ & $\begin{array}{l}\text { Данная статья устанавливает административную ответственность за воспрепятствование } \\
\text { эмитентом, акционерным инвестиционным фондом, управляющей компанией акционер- } \\
\text { ного инвестиционного фонда, паевого инвестиционного фонда или негосударственного } \\
\text { пенсионного фонда либо лицом, осуществляющим ведение реестра владельцев ценных } \\
\text { бумаг, осуществлению прав, удостоверенных ценными бумагами, за исключением случа- } \\
\text { ев, предусмотренных частями 1, 2, 4, 5, } 8 \text { и } 10 \text { статьи 15.23.1 КоАП РФ. }\end{array}$ \\
\hline $\begin{array}{c}\text { Статья } \\
15.24 .1 \\
\text { КоАП РФ }\end{array}$ & $\begin{array}{l}\text { Незаконные выдача } \\
\text { либо обращение до- } \\
\text { кументов, удостоверя- } \\
\text { ющих денежные и иные } \\
\text { обязательства }\end{array}$ & $\begin{array}{l}\text { Указанная статья устанавливает административную ответственность за незаконные выдачу } \\
\text { либо обращение ценных бумаг или удостоверяющих денежные и иные обязательства и не } \\
\text { являющихся ценными бумагами в соответствии с законодательством Российской Федера- } \\
\text { ции документов, за исключением случаев, предусмотренных статьями } 15.17 \text { и } 15.18 \text { КоАП } \\
\text { РФ, если эти действия не содержат уголовно наказуемого деяния. }\end{array}$ \\
\hline $\begin{array}{l}\text { Статья } \\
15.28 . \\
\text { КоАП РФ }\end{array}$ & $\begin{array}{l}\text { Нарушение правил при- } \\
\text { обретения более } 30 \text { про- } \\
\text { центов акций открытого } \\
\text { акционерного общества }\end{array}$ & $\begin{array}{l}\text { Указанная статья устанавливает ответственность за нарушение лицом, которое приобрело } \\
\text { более } 30 \text { процентов акций открытого акционерного общества, правил их приобретения. }\end{array}$ \\
\hline
\end{tabular}

Таблица 2.

\begin{tabular}{|c|c|c|}
\hline Норма & Наименование & Содержание \\
\hline $\begin{array}{c}\text { Статья } 15.19 \\
\text { КоАП РФ }\end{array}$ & $\begin{array}{c}\text { Нарушение } \\
\text { требований за- } \\
\text { конодательства, } \\
\text { касающихся } \\
\text { представления } \\
\text { и раскрытия } \\
\text { информации } \\
\text { на финансовых } \\
\text { рынках }\end{array}$ & 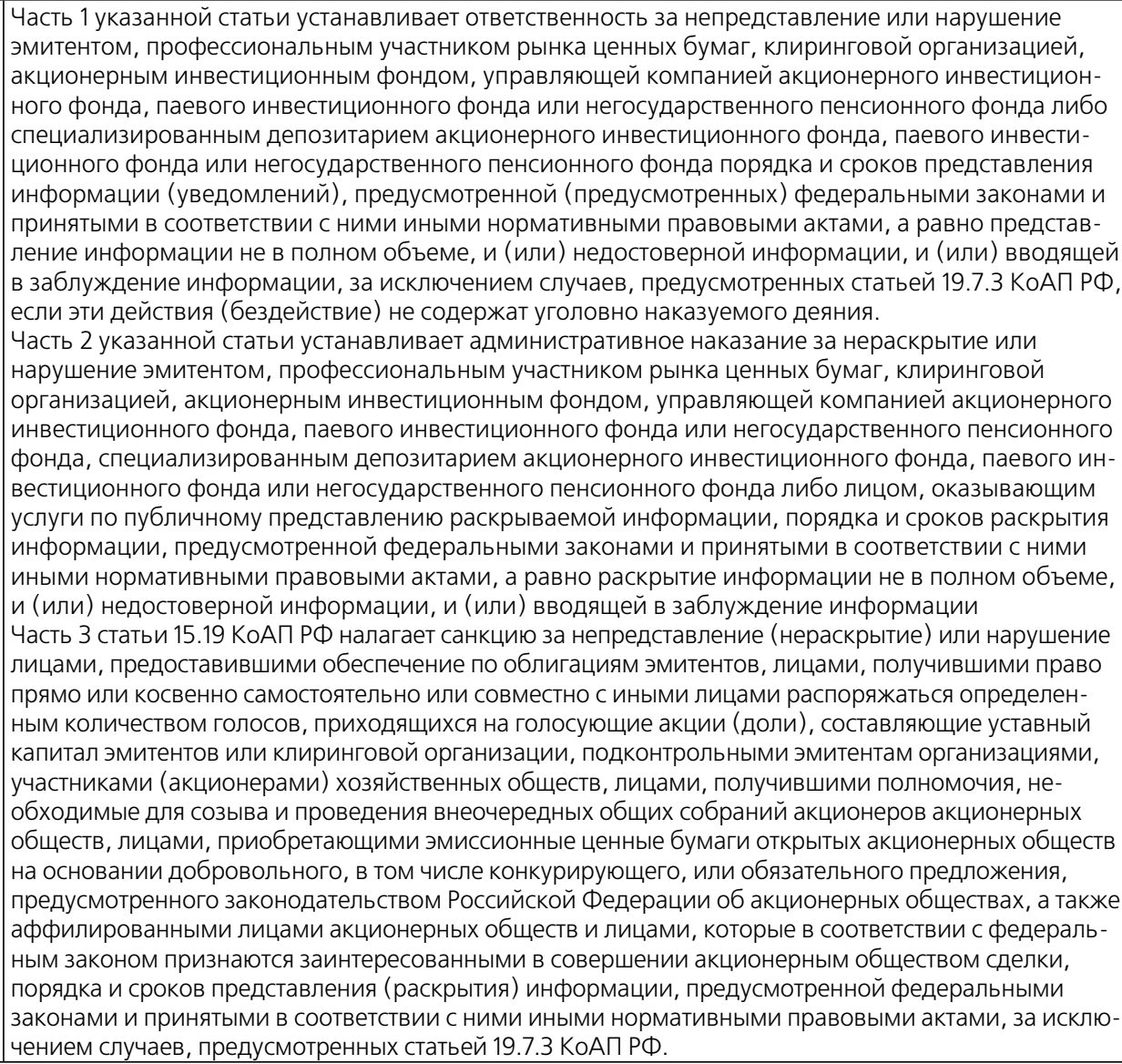 \\
\hline
\end{tabular}


Административное и муниципальное право 2 (86) 2015

Продолжение таблицы 2.

\begin{tabular}{|c|l|l|}
\hline Норма & Наименование & \multicolumn{1}{c|}{ Содержание } \\
\hline & $\begin{array}{l}\text { Часть 4 данной статьи устанавливает ответственность за нарушение стороной договора, заклю- } \\
\text { ченного не на организованных торгах на условиях генерального соглашения (единого договора), } \\
\text { установленных нормативными актами Банка России порядка и (или) сроков предоставления } \\
\text { информации об указанном договоре, в том числе предоставление неполной и (или) недостовер- } \\
\text { ной информации. }\end{array}$ \\
\hline
\end{tabular}

Таблица 3.

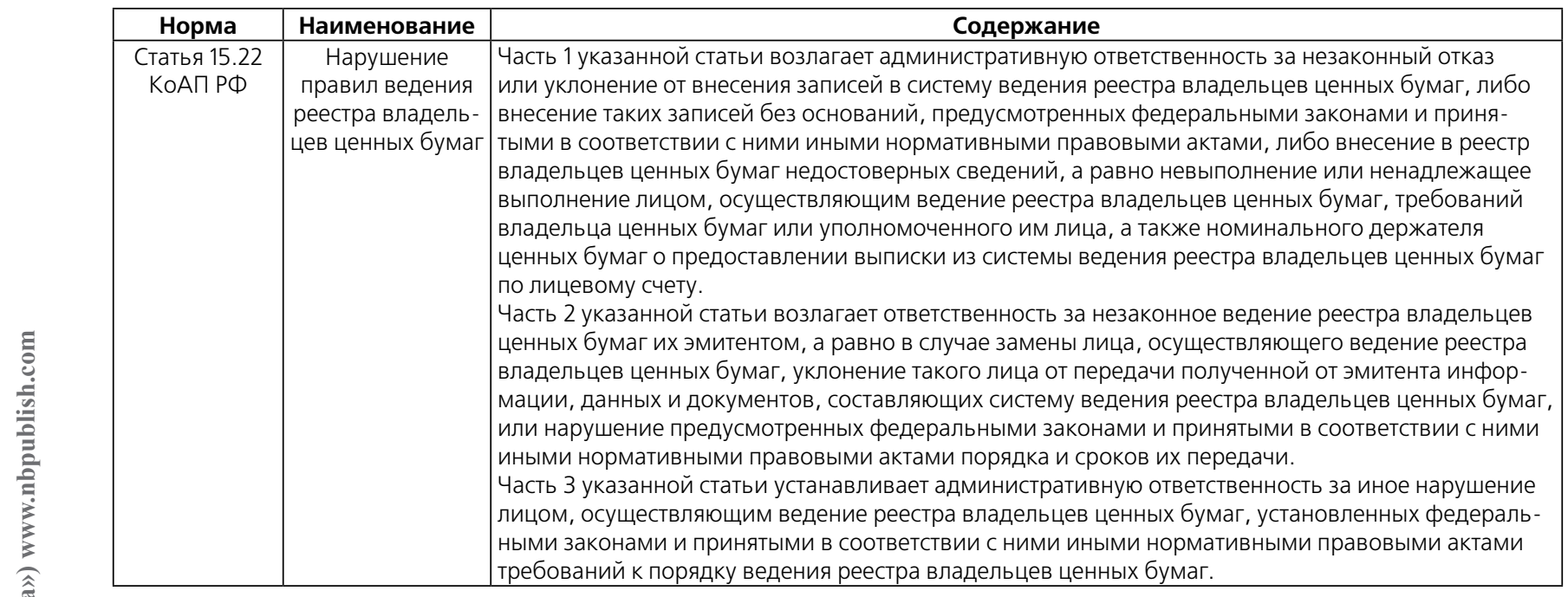

Таблица 4.

\begin{tabular}{|c|c|c|}
\hline Норма & Наименование & Содержание \\
\hline $\begin{array}{c}\text { Статья 15.23.1. } \\
\text { КоАП РФ }\end{array}$ & \begin{tabular}{|c|} 
Нарушение тре- \\
бований законо- \\
дательства о по- \\
рядке подготовки \\
и проведения \\
общих собраний \\
акционеров, \\
участников \\
обществ с огра- \\
ниченной (до- \\
полнительной) \\
ответственностью \\
и владельцев \\
инестиционных \\
паев закрытых \\
паевых инве- \\
стиционных \\
фондов).
\end{tabular} & 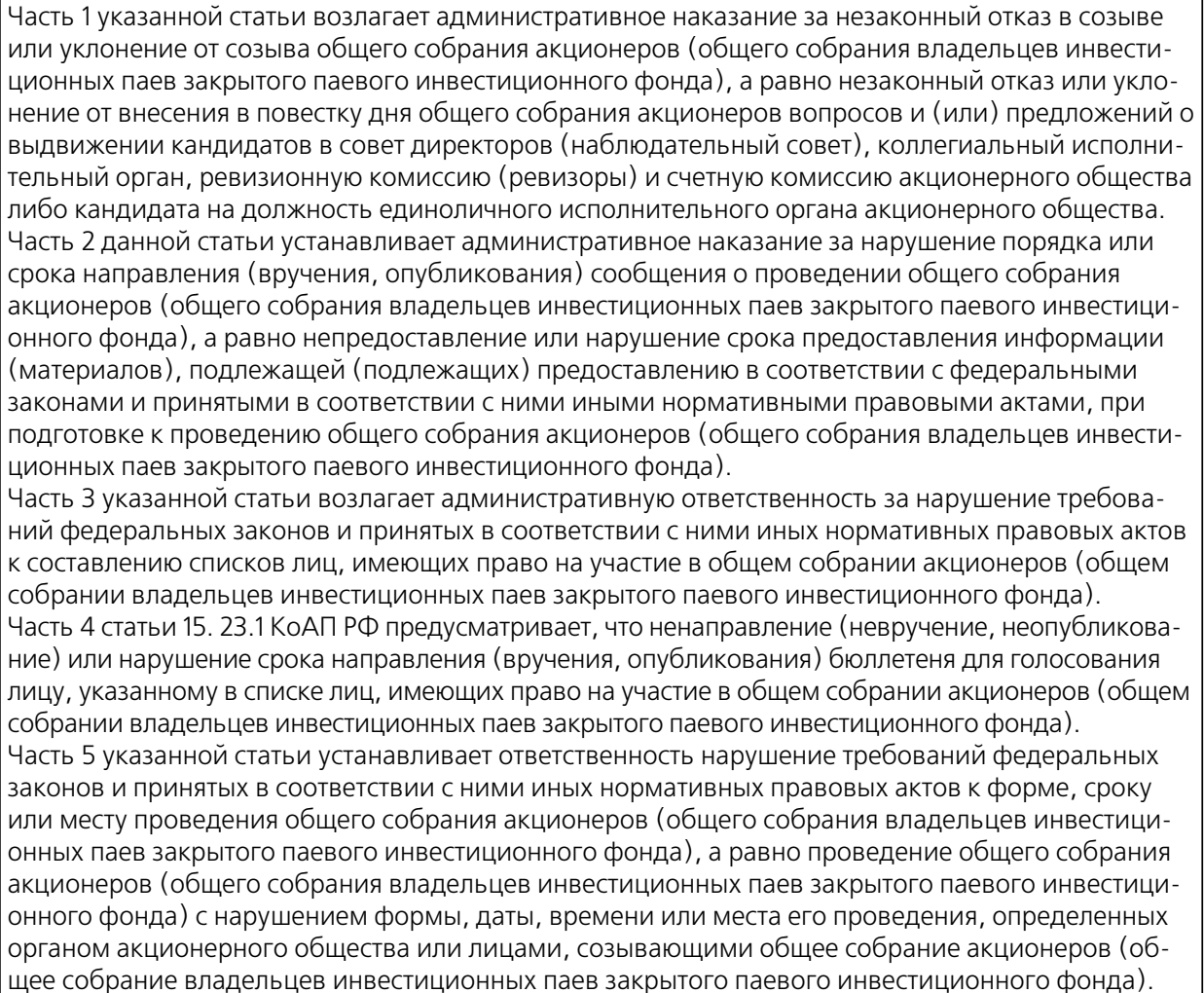 \\
\hline
\end{tabular}


Административная и муниципальная практика

Продолжение таблищы 4.

\begin{tabular}{|c|c|c|}
\hline Норма & Наименование & Содержание \\
\hline & & 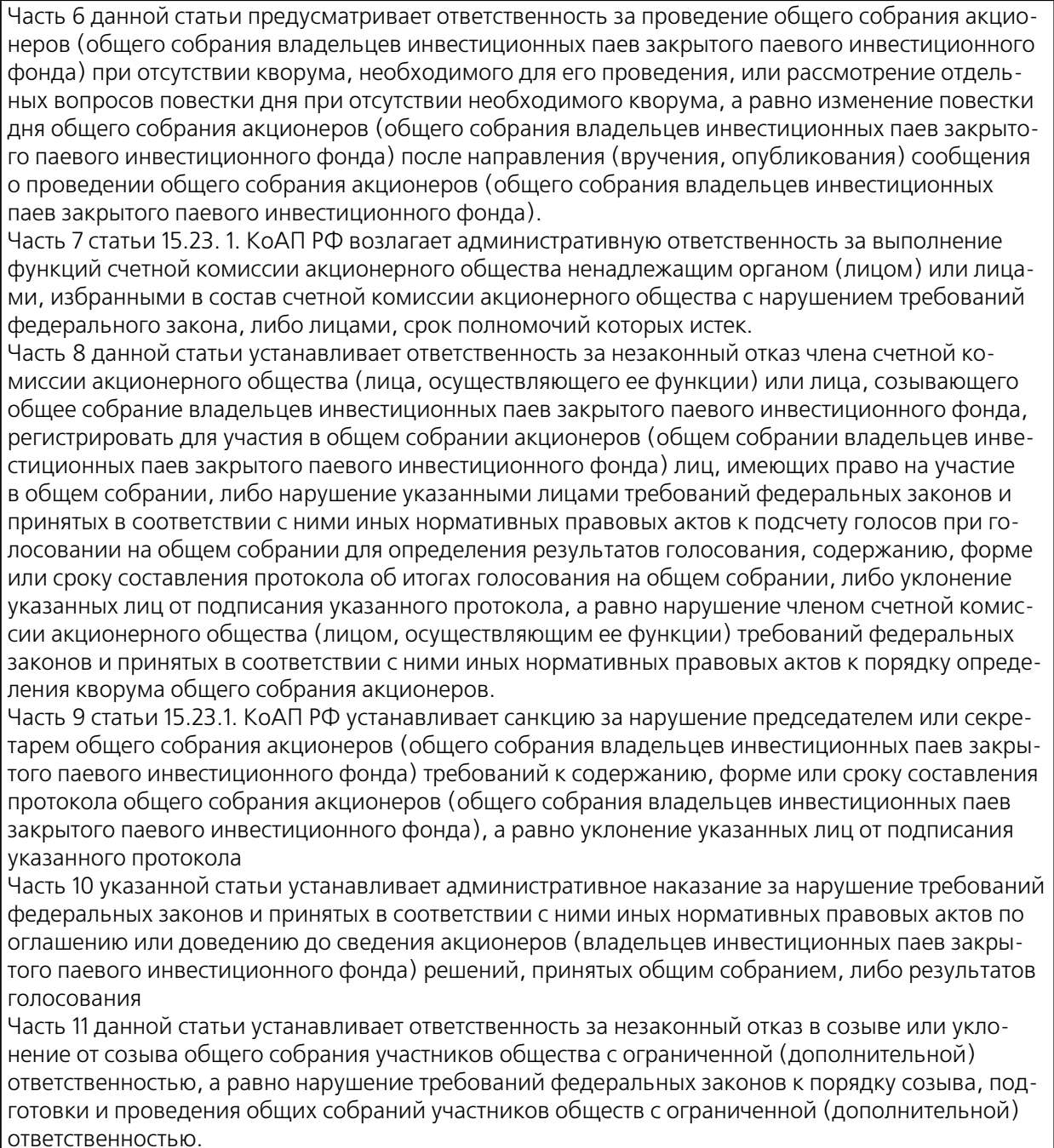 \\
\hline
\end{tabular}

Таблица 5.

\begin{tabular}{|c|c|c|}
\hline Норма & Наименование & Содержание \\
\hline $\begin{array}{c}\text { Статья } \\
15.29 \\
\text { КоАП РФ }\end{array}$ & $\begin{array}{l}\text { Нарушение требований законода- } \\
\text { тельства Российской Федерации, } \\
\text { касающихся деятельности професси- } \\
\text { ональных участников рынка ценных } \\
\text { бумаг, клиринговых организаций, } \\
\text { лиц, осуществляющих функции цен- } \\
\text { трального контрагента, акционерных } \\
\text { инвестиционных фондов, негосу- } \\
\text { дарственных пенсионных фондов, } \\
\text { управляющих компаний акцио- } \\
\text { нерных инвестиционных фондов, } \\
\text { паевых инвестиционных фондов } \\
\text { или негосударственных пенсионных } \\
\text { фондов, специализированных депо- } \\
\text { зитариев акционерных инвестицион- } \\
\text { ных фондов, паевых инвестицион- } \\
\text { ных фондов или негосударственных } \\
\text { пенсионных фондов }\end{array}$ & $\begin{array}{l}\text { Часть } 1 \text { указанной статьи возлагает санкцию за нарушение профессиональным } \\
\text { участником рынка ценных бумаг, клиринговой организацией, акционерным ин- } \\
\text { вестиционным фондом, управляющей компанией акционерного инвестиционно- } \\
\text { го фонда, паевого инвестиционного фонда или негосударственного пенсионного } \\
\text { фонда либо специализированным депозитарием акционерного инвестиционного } \\
\text { фонда, паевого инвестиционного фонда или негосударственного пенсионно- } \\
\text { го фонда установленных федеральными законами и иными нормативными } \\
\text { правовыми актами Российской Федерации требований к обособленному учету } \\
\text { собственных средств (имущества) и средств (имущества) клиентов. } \\
\text { Часть } 2 \text { указанной статьи устанавливает ответственность за нарушение профес- } \\
\text { сиональным участником рынка ценных бумаг, осуществляющим брокерскую или } \\
\text { дилерскую деятельность либо деятельность по управлению ценными бумагами, } \\
\text { установленных нормативными правовыми актами Российской Федерации пра- } \\
\text { вил ведения учета и составления отчетности. } \\
\text { Часть } 3 \text { возлагает ответственность за совершение профессиональным участником } \\
\text { рынка ценных бумаг, осуществляющим брокерскую деятельность либо деятель- } \\
\text { ность по управлению ценными бумагами, сделок по приобретению ценных бумаг } \\
\text { и имущественных прав, предназначенных для квалифицированных инвесторов, }\end{array}$ \\
\hline
\end{tabular}


Административное и муниципальное право 2 (86) 2015

Продолжение таблицы 5.

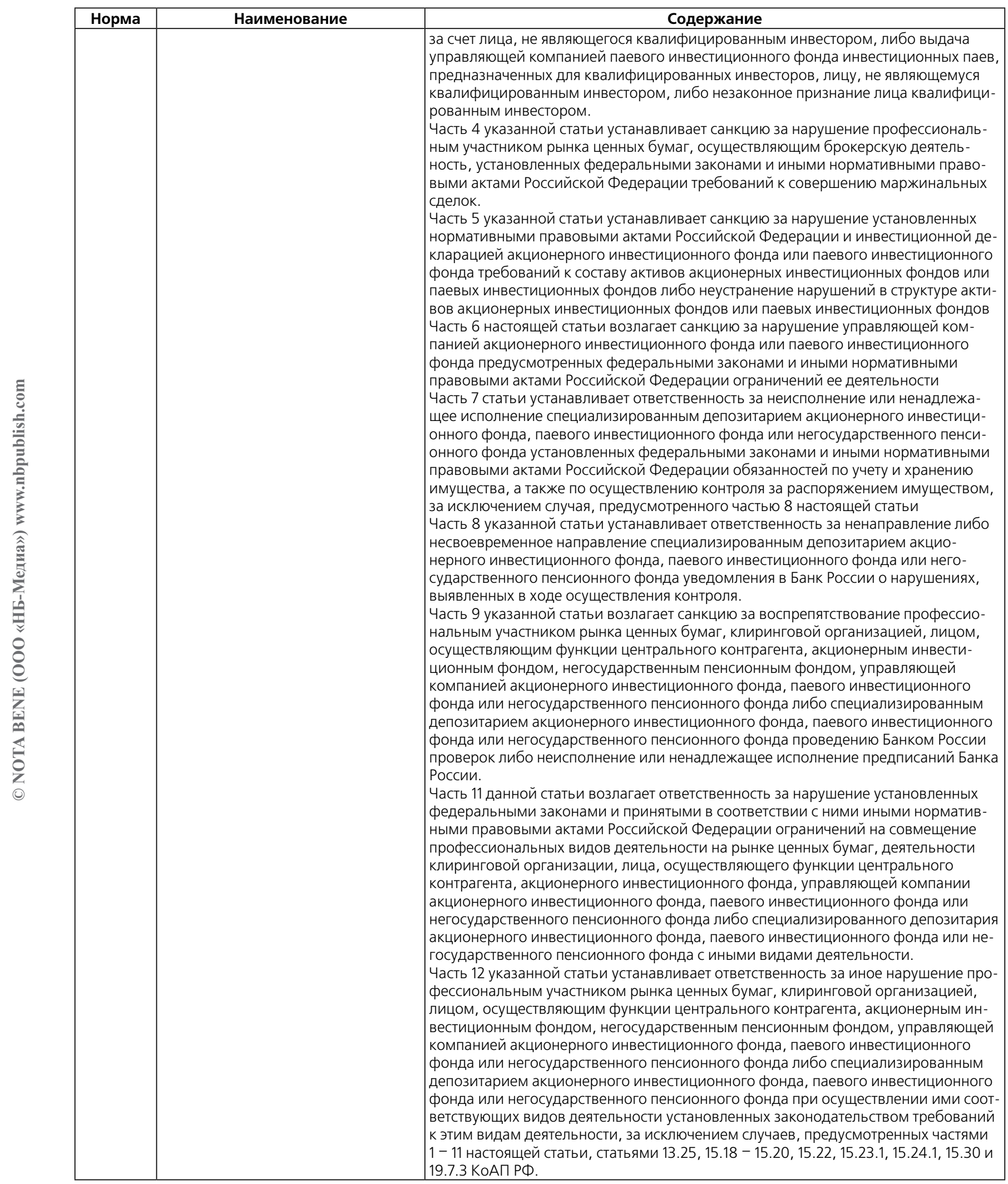


Следует отметить, что в качестве субъектов правонарушений в области рынка ценных бумаг могут выступать: 1) эмитенты; 2) владельцы ценных бумаг, а также профессиональные участники рынка ценных бумаг. Эмитентами в соответствии с положениями статьи 2 Федерального закона от 22 апреля 1996 года № 39-Ф3 «0 рынке ценных бумаг» являются юридические лица, исполнительные органы государственной власти, органы местного самоуправления, которые несут от своего имени или от имени публично-правового образования обязательства перед владельцами ценных бумаг по осуществлению прав, закрепленных этими ценными бумагамиㄹ․ Владельцами являются лица, которым ценные бумаги принадлежат на праве собственности или ином вещном праве.

Закон определяет профессиональных участников рынка ценных бумаг как юридических лиц, которые осуществляют виды деятельности, указанные в статьях $3-5,7$ и 8 Федерального закона «0 рынке ценных бумаг» (ст. 2 Закона «0 рынке ценных бумаг»). К таковым отнесены брокеры, дилеры, управляющие, депозитарии, регистраторы.

Осуществляя сравнительно-правовой анализ субъектных составов административных правонарушений в 15 главе КоАП РФ (в области финансов, налогов и сборов, страхования, рынка ценных бумаг), следует отметить, что в КоАП РФ изложен, по сути, исчерпывающий перечень субъектов по делам об административных правонарушениях в области рынка ценных бумаг, но, в то же время субъектный состав по административным правонарушениям в сфере налогов и финансов является рассредоточенным по различным кодифицирующим актам. Так, Налоговый кодекс Российской Федерации (часть 1) в качестве субъектов налоговых правонарушений устанавливает налогоплательщиков, под которыми в соответствии со статьёй 19 НК РФ признаются организации и физические лица, на которых в соответствии с положениями НК РФ возложена обязанность уплачивать, соответственно, налоги и (или) сборы. Бюджетный кодекс Российской Федерации в качестве субъектов правонарушений в сфере финансов предусматривает финансовые органы, под которыми статья 6 БК РФ понимает Министерство финансов Российской Федерации, органы исполнительной власти субъектов Российской Федерации, осуществляющие составление и организацию исполнения бюджетов субъектов Российской Федерации (финансовые

2 Федеральный закон от 22.04.1996 № 39-Ф3 (ред. от 28.12.2013) «О рынке ценных бумаг» (с изм. и доп., вступ. в силу с 01.07.2014) // РГ, № 79, 25.04. 1996. органы субъектов Российской Федерации), органы (должностные лица) местных администраций муниципальных образований, осуществляющие составление и организацию исполнения местных бюджетов (финансовые органы муниципальных образований).

Другим принципиальным отличием составов рассматриваемых правонарушений является то, что составы правонарушений в сфере финансов, налогов и сборов содержатся не только в КоАП РФ, но и в других федеральных законах - Бюджетном кодексе РФ и Налоговом кодексе РФ, в Федеральном законе о Банке России. По сути, имеет место юридическое дублирование составов правонарушений, имеющих административно-правовую природу, в различных нормативных правовых актах законодательного уровня. Это порождает определённые трудности в правоприменительной практике. Иначе обстоит дело с фиксацией административных правонарушений в области рынка ценных бумаг, которые, по сути, содержатся в одном кодифицирующем нормативном акте - КоАП РФ.

Последний вариант предлагается взять основу при реформировании административно-юрисдикционного законодательства в области финансов, налогов и сборов, страхования, рынка ценных бумаг. Необходимо объединить типологически схожие по объектам составы административных правонарушений, содержащиеся в КоАП РФ, Налоговом кодексе (часть 1) РФ и Бюджетном кодексе РФ, в законе о Банке России в единый федеральный Кодекс об административных правонарушениях. Налогоплательщики и финансовые органы не могут рассматриваться в качестве самостоятельных субъектов правонарушений в сфере налогов и финансов, так как являются по своей сути категориями синкретическими (собирательными), включающими юридических, физических лиц (налогоплательщики), а также органы государственной и местной власти (финансовые органы).

Выводы:

Анализ административных правонарушений в области рынка ценных бумаг, содержащихся в КоАП РФ, показывает, что в отличие от правонарушений в области финансов, налогов и сборов, административные правонарушения в указанной области, по сути, содержатся в одном кодифицированном нормативном правовом акте - КоАП РФ. Последний вариант представляется наиболее оптимальным и его необходимо взять за основу при реформировании административно-юрисдикционного законодательства в области финансов, налогов и сборов, страхования, рынка ценных бумаг. 


\section{Библиография:}

1. Конституция Российской Федерации. Принята всенародным голосованием 12.12.1993 (ред. от 05.02 .2014 № 2-ФКЗ) // Собрание законодательства РФ, 14.04.2014, № 15, ст. 1691.

2. Бюджетный кодекс Российской Федерации от 31.07.1998 № 145-Ф3 (ред. от 28.12.2013, с изм. от 03.02.2014) (с изм. и доп., вступ. в силу с 01.01.2014) // СЗ РФ, 03.08.1998, № 31, ст. 3823.

3. «Налоговый кодекс Российской Федерации (часть первая)» от 31.07.1998 № 146-Ф3 (ред. от 23.06.2014) (с изм. и доп., вступ. в силу с 01.07.2014) // СЗ РФ, № 31.08. 1998, ст. 3824.

4. Кодекс Российской Федерации об административных правонарушениях от 30.12 .2001 № 195 -Ф3 (ред. от 05.05.2014) (с изм. и доп., вступ. в силу с 22.06.2014) // СЗ РФ, 07.01.2002, № 1 (ч. 1), ст. 1.

5. Федеральный закон от 10.07.2002 № 86-Ф3 (ред. от 05.05.2014, с изм. от 28.06.2014) «О Центральном банке Российской Федерации (Банке России)» (с изм. и доп., вступ. в силу с 01.07.2014) // РГ, № 127, 13.07.2002.

6. Федеральный закон от 22.04.1996 № 39-ФЗ (ред. от 28.12.2013) «0 рынке ценных бумаг» (с изм. и доп., вступ. в силу с 01.07.2014) // РГ, № 79, 25.04. 1996.

7. Федеральный закон от 05.03.1999 № 46-ФЗ (ред. от 23.07.2013) «0 защите прав и законных интересов инвесторов на рынке ценных бумаг» // РГ, № 46, 11.03. 1999.

8. Федеральный закон от 29.11.2001 № 156-ФЗ (ред. от 12.03.2014) «Об инвестиционных фондах» (с изм. и доп., вступ. в силу с 01.07.2014) // РГ, № 237-238, 04.12.2001.

9. Г.В. Петрова Формирование международного права торговли финансовыми услугами и его влияние на национальное законодательство о финансовых рынках // Международное право и международные организации / International Law and International Organizations. - 2012. - 4. - C. 55 - 66.

10. Куракин А.В. Компетенция полиции в сфере реализации законодательства об административных правонарушениях // NB: Административное право и практика администрирования. - 2013. - 4. - C. 28 - 48. DOI: 10.7256/23069945.2013.4.8841. URL: http://www.e-notabene.ru/al/article_8841.html

11. Субанова Н.В. Административные правонарушения в сфере публичной разрешительной деятельности. // Административное и муниципальное право. - 2010. - 11. - С. 57 - 63.

12. Агапов А.Б. К вопросу о публичном принуждение в российском праве // NB: Административное право и практика администрирования. - 2013. - 7. - С. 58 - 87. DOI: 10.7256/2306-9945.2013.7.9922. URL: http://www.e-notabene. $\mathrm{ru} / \mathrm{al} /$ article_9922.html

13. Грекова И.Ю. Правовое регулирование рынка ценных бумаг // NB: Финансовое право и управление. - 2013. - 3. C. 53 - 62. DOI: 10.7256/2306-4234.2013.3.2880. URL: http://www.e-notabene.ru/flc/article_2880.html

14. Костенников М.В., Куракин А.В. К вопросу об основании административной ответственности в российском праве // NB: Административное право и практика администрирования. - 2013. - 10. - С. 75 - 88. DOI: 10.7256/23069945.2013.10.10153. URL: http://www.e-notabene.ru/al/article_10153.html

15. Ерпылева Н.Ю. Современное валютное регулирование в российском законодательстве // Право и политика. 2014. - 5. - C. 652 - 676. DOI: 10.7256/1811-9018.2014.5.11920.

16. Савчишкин Д.Б. К вопросу об административной ответственности в информационной сфере // Административное и муниципальное право. - 2011. - 5. - С. 64 - 72.

\section{References (transliterated):}

1. Konstitutsiya Rossiiskoi Federatsii. Prinyata vsenarodnym golosovaniem 12.12.1993 (red. ot 05.02.2014 № 2-FKZ) // Sobranie zakonodatel'stva RF, 14.04.2014, № 15, st. 1691.

2. Byudzhetnyi kodeks Rossiiskoi Federatsii ot 31.07.1998 № 145-FZ (red. ot 28.12.2013, s izm. ot 03.02.2014) (s izm. i dop., vstup. v silu s 01.01.2014) // SZ RF, 03.08.1998, № 31, st. 3823.

3. «Nalogovyi kodeks Rossiiskoi Federatsii (chast' pervaya)» ot 31.07.1998 № 146-FZ (red. ot 23.06.2014) (s izm. i dop., vstup. v silu s 01.07.2014) // SZ RF, № 31.08. 1998, st. 3824.

4. Kodeks Rossiiskoi Federatsii ob administrativnykh pravonarusheniyakh ot 30.12.2001 № 195-FZ (red. ot 05.05.2014) (s izm. i dop., vstup. v silu s 22.06.2014) // SZ RF, 07.01.2002, № 1 (ch. 1), st. 1.

5. Federal'nyi zakon ot 10.07.2002 № 86-FZ (red. ot 05.05.2014, s izm. ot 28.06.2014) «0 Tsentral'nom banke Rossiiskoi Federatsii (Banke Rossii)» (s izm. i dop., vstup. v silu s 01.07.2014) // RG, № 127, 13.07.2002.

6. Federal'nyi zakon ot 22.04.1996 № 39-FZ (red. ot 28.12.2013) «O rynke tsennykh bumag» (s izm. i dop., vstup. v silu s 01.07.2014) // RG, № 79, 25.04. 1996.

7. Federal'nyi zakon ot 05.03.1999 № 46-FZ (red. ot 23.07.2013) «0 zashchite prav i zakonnykh interesov investorov na rynke tsennykh bumag» // RG, № 46, 11.03. 1999.

8. Federal'nyi zakon ot 29.11.2001 № 156-FZ (red. ot 12.03.2014) «Ob investitsionnykh fondakh» (s izm. i dop., vstup. v silu s 01.07.2014) // RG, № 237-238, 04.12.2001. 
9. G.V. Petrova Formirovanie mezhdunarodnogo prava torgovli finansovymi uslugami i ego vliyanie na natsional'noe zakonodatel'stvo o finansovykh rynkakh // Mezhdunarodnoe pravo i mezhdunarodnye organizatsii / International Law and International Organizations. - 2012. - 4. - S. $55-66$.

10. Kurakin A.V. Kompetentsiya politsii v sfere realizatsii zakonodatel'stva ob administrativnykh pravonarusheniyakh // NB: Administrativnoe pravo i praktika administrirovaniya. - 2013. - 4. - S. 28 - 48. DOI: 10.7256/2306-9945.2013.4.8841. URL: http://www.e-notabene.ru/al/article_8841.html

11. Subanova N.V. Administrativnye pravonarusheniya v sfere publichnoi razreshitel'noi deyatel'nosti. // Administrativnoe i munitsipal'noe pravo. - 2010. - 11. - S. $57-63$.

12. Agapov A.B. K voprosu o publichnom prinuzhdenie v rossiiskom prave // NB: Administrativnoe pravo i praktika administrirovaniya. - 2013. - 7. - S. 58 - 87. DOI: 10.7256/2306-9945.2013.7.9922. URL: http://www.e-notabene.ru/al/ article_9922.html

13. Grekova I.Yu. Pravovoe regulirovanie rynka tsennykh bumag // NB: Finansovoe pravo i upravlenie. - 2013. - 3. - S. 53 62. DOI: 10.7256/2306-4234.2013.3.2880. URL: http://www.e-notabene.ru/flc/article_2880.html

14. Kostennikov M.V., Kurakin A.V. K voprosu ob osnovanii administrativnoi otvetstvennosti v rossiiskom prave // NB: Administrativnoe pravo i praktika administrirovaniya. - 2013. - 10. - S. 75 - 88. DOI: 10.7256/2306-9945.2013.10.10153. URL: http://www.e-notabene.ru/al/article_10153.html

15. Erpyleva N.Yu. Sovremennoe valyutnoe regulirovanie v rossiiskom zakonodatel'stve // Pravo i politika. - 2014. - 5. S. 652 - 676. DOI: 10.7256/1811-9018.2014.5.11920.

16. Savchishkin D.B. K voprosu ob administrativnoi otvetstvennosti v informatsionnoi sfere // Administrativnoe i munitsipal'noe pravo. - 2011. - 5. - S. $64-72$. 